\title{
Cumulated subsidence maps of Mexico City ${ }^{\text {th }}$
}

\section{Mapas de la subsidencia acumulada en la Ciudad de México}

\author{
Penélope López Quiroz ${ }^{\mathrm{a}}$, Marie-Pierre Doin ${ }^{\mathrm{b}}$, Iván Martínez Zazueta ${ }^{\mathrm{c}}$, Francisco Javier Osorno Covarrubias ${ }^{\mathrm{c}}$ \\ ${ }^{a}$ Centro de Geociencias, Universidad Nacional Autónoma de México, Blvd. Juriquilla No. 3001, Querétaro, 76230, México. \\ ${ }^{b}$ ISTerre, Université Grenoble-Alpes, CNRS, Grenoble, France \\ ${ }^{c}$ Laboratorio de Análisis Geo-Espacial (LAGE), Instituto de Geografía, Universidad Nacional Autónoma de México, Circuito Exterior, Ciudad Universitaria, \\ Coyoacán, 04510, México.
}

\begin{abstract}
In this work, we present a set of 38 rasters, with a $30 \times 30 \mathrm{~m}$ resolution, showing the cumulated subsidence over a large portion of Mexico City metropolitan area, from 20021122 (yyyymmdd) to 20070316. Annual average subsidence rates in Mexico City, one of the world most populated urban areas, reaches up to $0.38 \mathrm{~m} / \mathrm{yr}$, mainly due to soil compaction led by overexploitation of the Mexico Basin aquifer. To accurately map the spatial and temporal evolution of subsidence, a set of 38 Synthetic Aperture Radar (SAR) images from ENVISAT mission, has been processed through Small BASeline interferometry and the results have been formatted as rasters that can be analyzed on any Geographic Information System. Moreover, the whole set of rasters can be visualized as interactive animated series of cumulated subsidence maps through the journal platform.
\end{abstract}

Keywords: subsidence map; subsidence raster; InSAR; SAR; interferometry; SBAS; Mexico City; Mexico.

\section{Resumen}

En este trabajo, se presentan 38 rasters, con resolución de 30 x 30 m, que muestran la subsidencia acumulada sobre una gran porción de la Ciudad de México, desde 20021122 (aaaammdd), hasta 20070316. Las tasas de subsidencia promedio anual en la Ciudad de

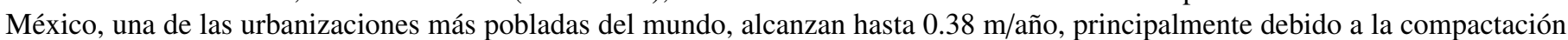
del suelo, provocada por la sobreexplotación del acuífero del Valle de México. Para mapear con exactitud la evolución espacial y temporal de la subsidencia, se procesó mediante interferometría con líneas de base pequeñas, un conjunto de 38 imágenes de Radar de Apertura Sintética de la misión ENVISAT. Los resultados fueron formateados como rasters que pueden ser analizados en cualquier Sistema de Información Geográfica. Además, el conjunto completo de rasters puede ser visualizado a través de la plataforma en línea de la revista, como serie de tiempo animada e interactiva de la subsidencia acumulada.

Palabras clave: mapa de subsidencia; raster de subsidencia; InSAR; SAR; interferometría; líneas de base pequeñas; Ciudad de México; México.

\section{Introduction}

Maps constitute a useful tool to analyze subsidence taking place in large urban areas like Mexico City, where water pumping exceed the aquifer replenishment. Moreover, when maps

\footnotetext{
(C) Penélope López Quiroz, Marie Pierre Doin, Iván Martínez Zazueta \& Francisco Javier Osorno Covarrubias. Published by Terra Digitalis.

This is an Open Access article distributed under the terms of the Creative Commons Attribution License (https://creativecommons.org/licenses/by-nc-sa/4.0/), which permits non-commencial sharing of the work and adaptions, provided the original work is properly cited and the new creations are licensed under identical terms.

*E-mail address: penelope@geociencias. unam.mx
}

are updated in time, the spatial and time evolution of subsidence can be estimated, constituting a great tool to asses the generation of strategies to cope with the consequences of this kind of hazard. Subsidence measurements, can be achieved by using several techniques including leveling, Global Positioning System (GPS), extensometers, piezometers, Light Detection and Ranging (LIDAR), cameras carried by Unmanned Aerial Vehicles (UAV), and Synthethic Aperture Radar Interferometry (InSAR). In a way, all these techniques can be complementary, however, most of them (e.g. leveling, GPS, extensometers, piezometers) require in-situ tool installation and measuring; besides, spatial resolution can be poor, because measurements can 
be obtained only at a few locations. Mapping, using cameras carried by UAV, can be done when the extension of the study area is not very large (Carrera Hernández et al., 2016). However, when subsidence has to be measured over large areas, InSAR is a valuable tool, because is usually less expensive than LIDAR or obtaining measurements from techniques based on labor intensive surveys. Moreover, results from InSAR can be used as a first step to guide the subsequent installation of GPS, leveling and extensometer/piezometer, over specific and limited areas (Galloway and Burbey, 2011).

InSAR has been successfully applied to monitor subsidence (Amelung et al., 1999; Cavalié et al., 2007; Hooper et al., 2004). For this purpose, it is possible to use one of the following two approaches. The first one, is known as Differential SAR Interferometry (DInSAR), and consists in making interfere two images, taken at two different times from the same study area, to measure the deformation occurred on the time span between the acquisition of the two images. The second one, is known as Advanced InSAR (A-DInSAR) and overcomes most of the problems encountered by DInSAR (e.g. atmospheric phase contribution modeling and removal), using several images. Among principal A-DInSAR techniques are the processing of Small BASelines interferograms (SBAS), and the Permanent or Persistent Scatterers (PS). Both of them, allow to generate deformation time series: a) over the pixels that constitute the images, when using SBAS, and b) over targets with a level of coherence constant in time (e.g. buildings or pinnacles), when using PS (Del Ventisette et al., 2013). Examples of DInSAR and A-DinSAR applied to subsidence due to water pumping were presented by Berardino et al., 2002; Schmidt and Bürgmann, 2003; Usai, 2003; Ferretti, Prati, and Rocca, 2000; Galloway and Hoffmann, 2007 and Galloway and Burbey, 2011.

Maps of the Mexico City subsidence have been obtained in the past. Strozzi et al., 2003 and Cabral Cano et al., 2008, used DInSAR, reporting annual maximum subsidence rates of $0.50 \mathrm{~m} / \mathrm{yr}$ and $0.38 \mathrm{~m} / \mathrm{yr}$, respectively. Osmanoğlu et al., 2011, Yan et al., 2012 and Chaussard et al., 2014, used A-DInSAR to present annual average subsidence maps, reporting maximum subsidence rates of $0.30 \mathrm{~m} / \mathrm{yr}, 0.35$ and $0.38 \mathrm{~m} / \mathrm{yr}$, and 0.30 $\mathrm{m} / \mathrm{yr}$, respectively. It is important to note that, even if these works calculated time series of subsidence over the city, the corresponding images were not presented or available. LópezQuiroz et al., 2009, used SBAS (A-DInSAR) interferometry to calculate the time series and annual average subsidence, of each $30 \times 30 \mathrm{~m}$ pixel, in Mexico City metropolitan area, for a time span of 4 years and 4 months, from 20021122 to 20070316. However, they only presented the annual average subsidence map. This work makes available the complete database of the time series presented by López-Quiroz et al., 2009, and offers an interactive animated visualization of the series of subsidence maps, which can be seen on the Terra Digitalis platform. Rasters constituting the database, can be downloaded and analyzed on any Geographic Information System.

\section{Mexico City subsidence}

The Mexico City metropolitan area extends over $1200 \mathrm{~km} 2$ and is considered the third most populated urban agglomeration in the world (Benson et al., 2016). Overpopulation leads to very large water consumption, in turn leading to an excessive aquifer water pumping. Subsidence is believed to be correlated with overexploitation of the aquifer and has been affecting Mexico City metropolitan area for a century, i.e. since ground water pumping began. Its consequences include the damage of important urban structures, like water and gas supply pipelines, drainage pipes, as well as domestic and historical buildings (Santoyo-Villa et al., 2005). Subsidence also contributes to recurrent flooding during the rainy season. For all of the above, accurate maps of the Mexico City subsidence are needed to assess and prevent the related risks and consequences.

\section{Hydrogeological setting}

Mexico City is located into the southern part of an endoreic basin which hydrogeological setting can be simplified as an aquifer and an aquitard. The aquifer, is composed of Quaternary alluvial deposits, its depth is spatially variable and can reach a maximum of $800 \mathrm{~m}$ (Herrera et al., 1989). The aquitard, partially covers the aquifer and consists of Quaternary lacustrine deposits. Its depth is also spatially variable and can reach a maximum of $300 \mathrm{~m}$ (Vázquez-Sánchez and Jaimes-Palomera, 1989). Lacustrine deposits of the aquitard are mainly composed of extremely compressible clays that undergo compaction because of the high water extraction from the aquifer, resulting in widespread subsidence (Carrera-Hernández and Gaskin, 2007).

\section{Methodology}

To analyze the temporal and spatial evolution of the Mexico City subsidence phenomena, a set of 38 SAR images from the ENVISAT satellite, provided by the European Space Agency and covering the 20021122 to 20070316 time span, were acquired and processed. A 3-arc second sampled, void filled, Digital Elevation Model from the Shuttle Radar Topography Mission (Farr and Kobrick, 2000), was used to remove topography from the interferograms. We performed an SBAS processing chain, selecting interferograms having less than 9 months of temporal baseline and less than $500 \mathrm{~m}$ of perpendicular baseline. The total number of calculated interferograms was 71. All of them were processed using the JPL-CalTech Repeat Orbit Interferometry Package (ROI_PAC) (Rosen et al., 2004). A dedicated algorithm was then applied to solve the unwrapping problems of some of the interferograms; including the use of a stack of interferograms and the atmospheric correction of the vertically stratified tropospheric phase (Cavalié et al., 2007, LópezQuiroz et al., 2009). The 71 interferograms were then inverted to derive the deformation time series of each $30 \times 30 \mathrm{~m}$ pixel (Cavalié et al., 2007). Finally, time deformation series were converted to 38 rasters, representing the cumulated subsidence 
for dates included in Table 1. The first date, 20021122, represents the reference date, so its cumulated subsidence is zero everywhere. The last date, 20070316, represents the cumulated subsidence for the total time span of 4 years and 4 months and is presented in Plate 1. The latter means that, for each pixel of $30 \times 30 \mathrm{~m}$, we have presented and made available, a time series of cumulated subsidence over 38 dates. Further details on the development of the processing steps are described in LópezQuiroz et al., 2009. The main difference with the results presented here is that previously, for each pixel of $30 \times 30 \mathrm{~m}$, only the annual subsidence average velocity was presented.

Table 1: Dates of the 38 processed images, also labeling the 38 cumulated subsidence rasters. The first date, 20021122 (yyyymmdd), represents the reference date, thus its cumulated deformation equals zero all over the raster. Tabla 1. Fechas de las 38 imágenes procesadas, las cuales etiquetan los 38 rasters de subsidencia acumulada. La primera fecha, 20021122 (aaaammdd), representa la fecha de referencia, por lo que su deformación acumulada es cero en todo el ráster.

\begin{tabular}{|c|c|}
\hline Raster no. & Raster date \\
\hline 1 & 20021122 \\
\hline 2 & 20030307 \\
\hline 3 & 20030411 \\
\hline 4 & 20030620 \\
\hline 5 & 20030725 \\
\hline 6 & 20030829 \\
\hline 7 & 20031003 \\
\hline 8 & 20031107 \\
\hline 9 & 20031212 \\
\hline 10 & 20040116 \\
\hline 11 & 20040220 \\
\hline 12 & 20040326 \\
\hline 13 & 20040430 \\
\hline 14 & 20040604 \\
\hline 15 & 20040813 \\
\hline 16 & 20040917 \\
\hline 17 & 20041022 \\
\hline 18 & 20041126 \\
\hline 19 & 20041231 \\
\hline 20 & 20050204 \\
\hline 21 & 20050311 \\
\hline 22 & 20050415 \\
\hline 23 & 20050520 \\
\hline 24 & 20050624 \\
\hline 25 & 20050729 \\
\hline 26 & 20050902 \\
\hline 27 & 20051007 \\
\hline 28 & 20051111 \\
\hline 29 & 20051216 \\
\hline 30 & 20060120 \\
\hline 31 & 20060224 \\
\hline 32 & 20060331 \\
\hline 33 & 20060505 \\
\hline 34 & 20060609 \\
\hline 35 & 20061201 \\
\hline 36 & 20070105 \\
\hline 37 & 20070209 \\
\hline 38 & 20070316 \\
\hline
\end{tabular}

\section{Results and discussion}

Annual average velocity calculated from time series on some pixels, were compared to selected GPS measurements (CabralCano et al., 2008). The overall agreement between both measurements was good, although differences up to $0.023 \mathrm{~m} / \mathrm{yr}$ were observed, which is well below given error bars (see LópezQuiroz et al., 2009). The discrepancy can be due to the spatial characteristics of the two measurements: GPS estimates subsidence at a point, while SBAS interferometry, used in this work, average it for a $30 \times 30 \mathrm{~m}$ area. However, a more detailed quantitative study would be needed in order to accurately compare both measurements. Maximum cumulated subsidence for the whole time span, occurs in the Nezahualcoyotl $(1.66 \mathrm{~m})$ and Tlahuac $(1.33 \mathrm{~m})$ areas, where annual average subsidence velocities are 0.38 and $0.31 \mathrm{~m} / \mathrm{yr}$, respectively. The complete set of 38 rasters can be used to analyze zones of maximum deformation gradient and to assess damage to urban infrastructure in the city, since differential subsidence can be more dangerous than the magnitude of the annual average subsidence. The rasters were uploaded to a geospatial server and published in an interactive dynamic geo-visualizer, allowing the visualization of the animated series of cumulated subsidence maps.

\section{Conclusions}

With this work, we made available a set of 38 rasters of cumulated subsidence over Mexico City, from 20021122 to 20070316. The dynamic geo-visualizer on the journal platform allows to represent the temporal and spatial evolution of subsidence in Mexico City. With this tool, it is possible to determine which zones of Mexico City and its metropolitan area have accumulated more subsidence and how this process evolved in time. This work may help to identify the subsurface heterogeneities that control the pattern of subsidence and to plan prevention actions in specific areas.

\section{Software and map design}

Information technologies enable the development of online, real-time, multi-scale, interoperable, open and collaborative monitoring systems for different geospatial products. The dynamic and animated visualization of subsidence and similar information from the geography and geosciences areas, allows to visualize its evolution over time, in order to determine historical trends and possible scenarios of vulnerability and risk, revealing the value of this kind of tools for the scientific knowledge production at international scale. Open source Geographic Resources Analysis Support System (GRASS GIS), was used to format the 38 cumulated subsidence rasters. ArcGIS by ESRI, was also used to create the project containing the corresponding 38 rasters layers and its related color scale. Geoserver and Geonode were used for the publication of online geospatial data. The geo-visualizer was developed with OpenLayers library and PHP programming Language. All this software is open source. 


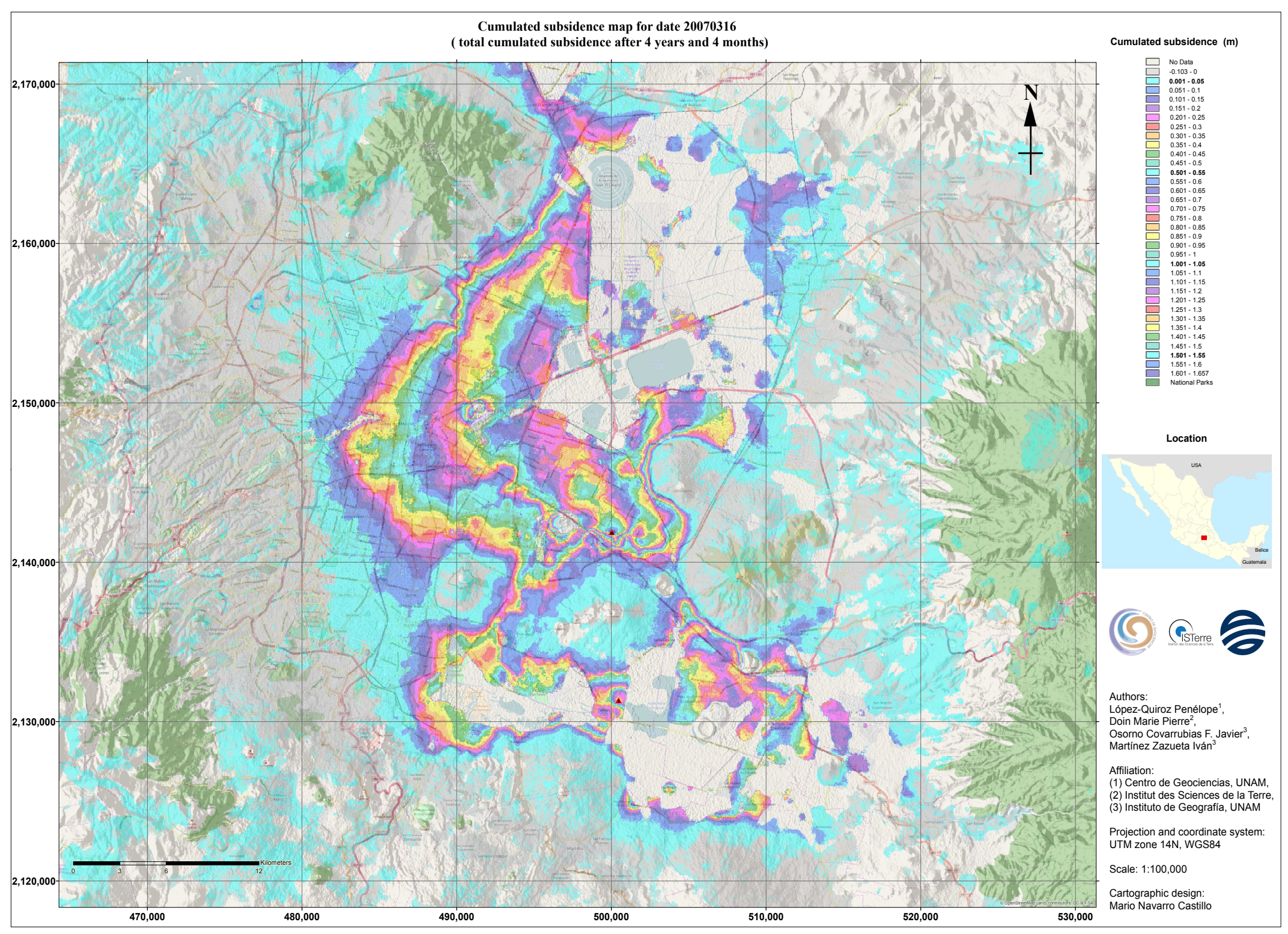

Plate 1. Cumulated subsidence map for date 20070316, i.e. total cumulated subsidence for the time span between 20021122 and 20070316 ( 4 years and 4 months). Cumulated subsidence areas showing negative and zero magnitudes are represented by color gray. The color scale repeats every $0.5 \mathrm{~m}$. Each color contour represent an area with the same cumulated subsidence (iso-deformation curve). Maximum cumulated subsidence occurs in the Nezahualcoyotl $(1.66 \mathrm{~m})$ and Tlahuac $(1.33 \mathrm{~m})$ zones, represented with red triangles $\mathrm{N}$ and T, respectively.

Lámina 1. Mapa de la subsidencia acumulada para la fecha 20070316, esto es, subsidencia total acumulada en el periodo comprendido entre 20021122 y 20070316 (4 años con 4 meses). Las áreas con subsidencia acumulada negativa o igual a cero están representadas con el color gris. La escala de color se repite cada $0.5 \mathrm{~m}$. Cada curva o contorno de color, representa un área con la misma subsidencia acumulada (curva de isodeformación). La máxima subsidencia acumulada ocurre en las zonas de Nezahualcóyotl (1.66 m) y Tláhuac (1.33 m), representadas con los triángulos rojos $\mathrm{N}$ y T, respectivamente. 


\section{Acknowlegments}

Special thanks go to Mario Edgar Navarro Castillo, who contributed to the cartographic design and development of the ArcGIS associated project. This work was made possible thanks to the Mexican National Science and Technology Council (Conacyt) and its financial support through a PhD grant No. 200674. Reviews by E. Cabral and L. Ferrari helped to improve the clarity of the work.

\section{References}

Amelung, F., Galloway, D. L., Bell, J. W., Zebker, H. A., Laczniak, R. J., 1999. Sensing the ups and downs of Las Vegas: InSAR reveals structural control of land subsidence and aquifer-system deformation. Geology 27 (6), 483486, DOI: https://doi.org/10.1130/0091-7613(1999)027<0483: STUADO $>2.3 . \mathrm{CO} ; 2$

URL: http://geology.gsapubs.org/content/27/6/483

Benson-Lira, V., Georgescu, M., Kaplan, S., Vivoni, E. R., 2016. Loss of a lake system in a megacity: The impact of urban expansion on seasonal meteorology in Mexico City. Journal of Geophysical Research: Atmospheres 121 (7), 3079-3099, DOI: https ://doi .org/10.1002/2015JD024102.

Berardino, P., Fornaro, G., Lanari, R., Sansosti, E., 2002. A new algorithm for surface deformation monitoring based on small baseline differential SAR interferograms. IEEE Transactions on Geoscience and Remote Sensing 40 (11), 2375-2383, DOI: https ://doi .org/10.1109/TGRS . 2002. 803792.

Cabral Cano, E., Dixon, T. H., Miralles Whilhelm, F., Diaz Molina, O., Sanchez Zamora, O., Carande, R. E., 2008. Space geodetic imaging of rapid ground subsidence in Mexico City. Geological Society of America BulletinDOI: https://doi .org/10.1130/B26001.1.

Carrera Hernández, J. J., Gaskin, S. J., 2007. The Basin of Mexico aquifer system: regional groundwater level dynamics and database development. Hydrogeology Journal 15 (8), 1577-1590, DOI: https://doi.org/10. $1007 /$ s 10040-007-0194-9.

Carrera Hernández, J. J., Levresse, G., Lacan, P., Aranda Gómez, J. J., 2016. A low cost technique for development of ultra-high resolution topography: application to a dry maar's bottom. Revista Mexicana de Ciencias Geológicas 33 (1), 122-133.

Cavalié, O., Doin, M. P., Lasserre, C., Briole, P., 2007. Ground motion measurement in the Lake Mead area, Nevada, by differential synthetic aperture radar interferometry time series analysis: Probing the lithosphere rheological structure. Journal of Geophysical Research: Solid Earth. DOI: https://doi.org/10.1029/2006JB004344.

Chaussard, E., Wdowinski, S., Cabral-Cano, E., Amelung, F., 2014. Land subsidence in central Mexico detected by ALOS InSAR time-series. Remote Sensing of Environment 140, 94-106, DOI: https://doi.org/10.1016/j.rse.2013.08.038.

URL: http://www.sciencedirect.com/science/article/pii/ S0034425713002964

Del Ventisette, C., Ciampalini, A., Manunta, M., Calò, F., Paglia, L., Ardizzone, F., Mondini, A. C., Reichenbach, P., Mateos, R. M., Bianchini, S., Garcia, I., Füsi, B., Deák, Z. V., Rádi, K., Graniczny, M., Kowalski, Z., Piatkowska, A., Przylucka, M., Retzo, H., Strozzi, T., Colombo, D., Mora, O., Sánchez, F., Herrera, G., Moretti, S., Casagli, N., Guzzetti, F., 2013. Exploitation of large archives of ERS and ENVISAT C-band SAR data to characterize ground deformations. Remote Sensing 5 (8), 3896-3917, DOI: https://doi.org/10.3390/rs5083896.

Farr, T. G., Kobrick, M., 2000. Shuttle Radar Topography Mission produces a wealth of data. Eos, Transactions American Geophysical Union 81 (48), 583-585, DOI: https://doi .org/10.1029/E0081i048p00583.
Ferretti, A., Prati, C., Rocca, F., 2000. Nonlinear subsidence rate estimation using permanent scatterers in differential SAR interferometry. IEEE Transactions on Geoscience and Remote Sensing 38 (5), 2202-2212, DOI: https://doi.org/10.1109/36.868878.

Galloway, D. L., Burbey, T. J., 2011. Review: Regional land subsidence accompanying groundwater extraction. Hydrogeology Journal 19 (8), 1459-1486, DOI: https://doi.org/10.1007/s10040-011-0775.

Galloway, D. L., Hoffmann, J., 2007. The application of satellite differential SAR interferometry-derived ground displacements in hydrogeology. Hydrogeology Journal 15 (1), 133-154, DOI: https://doi.org/10.1007/ s10040-006-0121-5.

Herrera, I., Martínez, R., Hernández, G., 1989. Contribución para la administración científica del agua subterránea de la Cuenca de México [Contribution for the scientific management of groundwater in the basin of mexico]. Geofísica Internacional 28 (2), 297-334.

Hooper, A., Zebker, H., Segall, P., Kampes, B., 2004. A new method for measuring deformation on volcanoes and other natural terrains using InSAR persistent scatterers. Geophysical Research Letters 31 (23), L23611, DOI: https://doi .org/10.1029/2004GL021737.

URL: http://onlinelibrary.wiley.com/doi/10.1029/ 2004GL021737/abstract

López-Quiroz, P., Doin, M.-P., Tupin, F., Briole, P., Nicolas, J.-M., 2009. Time series analysis of Mexico City subsidence constrained by radar interferometry. Journal of Applied Geophysics 69 (1), 1-15, DOI: https://doi.org/10.1016/j.jappgeo.2009.02.006.

URL: http://www.sciencedirect.com/science/article/pii/ S0926985109000251

Osmanoğlu, B., Dixon, T. H., Wdowinski, S., Cabral-Cano, E., Jiang, Y., 2011. Mexico City subsidence observed with persistent scatterer InSAR. International Journal of Applied Earth Observation and Geoinformation 13 (1), 1-12, DOI: https ://doi.org/10.1016/j.jag.2010.05.009. URL: http://www.sciencedirect.com/science/article/pii/ S0303243410000644

Rosen, P. A., Hensley, S., Peltzer, G., Simons, M., 2004. Updated repeat orbit interferometry package released. EOS Transactions American Geophysical Union 85 (5), DOI: https://doi .org/10.1029/2004E0050004.

Santoyo-Villa, E., Ovando-Shelley, E., Mooser, F., León-Plata, E., 2005. Síntesis geotécnica de la cuenca del Valle de México. TGC Geotecnia, México.

Schmidt, D. A., Bürgmann, R., 2003. Time-dependent land uplift and subsidence in the Santa Clara valley, California, from a large interferometric synthetic aperture radar data set. Journal of Geophysical Research: Solid Earth 108 (B9), DOI: https : //doi .org/10.1029/2002JB002267.

Strozzi, T., Wegmuller, U., Werner, C. L., Wiesmann, A., Spreckels, V., 2003. JERS SAR interferometry for land subsidence monitoring. IEEE Transactions on Geoscience and Remote Sensing 41 (7), 1702-1708, DOI: https : //doi.org/10.1109/TGRS. 2003.813273.

Usai, S., 2003. A least squares database approach for SAR interferometric data. IEEE Transactions on Geoscience and Remote Sensing 41 (4), 753-760, DOI: https://doi .org/10.1109/TGRS. 2003.810675.

Vázquez-Sánchez, E., Jaimes-Palomera, R., 1989. Geología de la Cuenca de México. Geofísica Internacional 28 (2), 133-190.

Yan, Y., Doin, M. P., Lopez-Quiroz, P., Tupin, F., Fruneau, B., Pinel, V., Trouve, E., 2012. Mexico City Subsidence Measured by InSAR Time Series: Joint Analysis Using PS and SBAS Approaches. IEEE Journal of Selected Topics in Applied Earth Observations and Remote Sensing 5 (4), 1312-1326, DOI: https://doi.org/10.1109/JSTARS.2012.2191146.

This article accompanies the following material:

HTML: $\quad$ DOI: 10.22201/igg.terradigitalis.2017.1.11.41

Dynamic map: DOI: 10.22201/igg.terradigitalis.2017.1.11.57

Static map: $\quad$ DOI: 10.22201/igg.terradigitalis.2017.1.11.62 